\title{
16. The erosion of judicial independence
}

\section{Graham Leung}

Fifteen months after the coup, Fiji is drifting inexorably towards the abyss. As every day goes by, new examples of the capricious and unprincipled assertion of power without authority emerge. The new status quo is the product of an equilibrium of fear - on the one hand, the people fear the instruments of power and being pressed into silence and, on the other hand, those who wield power in Fiji fear the light of any objective scrutiny and debate. As a result, the authorities have become habituated to the use of coercion and intimidation to control the free circulation of ideas and beliefs. Intimidation, coercion and oppression have become the working tools by which an unholy alliance of opportunists and miscreants is being maintained in power. The national conversation about the most important issue of the century has been silenced. The people fear the government and the government fears its own people. What has happened to Fiji, romanticized in happier times by its people as 'The way the world should be'?

Over the past year or so, we have been given countless lectures on the need for good governance, accountability and transparency. The US State Department Country Report on Fiji for 2007 concluded 'much government decision making was not transparent'. Fiji's citizens have been denied the government they elected and must live in fear of that which has displaced it. They have been repeatedly told that 'the Constitution is still intact' and that is has not been abrogated. And yet the constitutional framework of government has been swept away and replaced by what amounts to a far from benign dictatorship. We have been reassured that the interim regime supports not just the rule of law, but the spirit behind it. And yet, our Court of Appeal judges have resigned en masse, our Chief Justice is summarily turned out of his office, and all the voices of protest and outrage within the country are silenced by the threat that they will be prosecuted as being racially intolerant or a danger to national security. It is appropriate to ask what has been the administration's record, judged by its own standards? Do its actions match its rhetoric? Does it practice what it preaches? Or is this a case of 'do as I say, not as I do'?

A few brief and far from definitive examples illustrate the point:

- Civilians who have questioned the regime have been variously described as liars, corrupt, opportunistic, power-hungry troublemakers bent on inciting 
disaffection. Some have been arrested, assaulted, detained, humiliated and/or threatened by military personnel. Some have died.

- The right to dissent and freedom of expression is circumscribed.

- Most dissenters have been denigrated and harangued, often in expensive advertisements paid from the public purse. Others have been harassed and slapped with travel bans.

- The media has practiced self-censorship and been regularly criticized.

- In contrast, collaborators and sympathizers have been rewarded with appointments to seats on various government companies and boards.

The fiction that all that is being done is within the constitution is central to the moral claims of the interim government. It permits those responsible to cloak themselves in virtue. It is by this fiction that many have fallen into the conversationally convenient, but legally wrong, habit of referring to those responsible as a 'government'.

What we are effectively seeing is a re-writing of history. The 'victors' are sanitizing the record.

\section{Transparency}

The architects of the 'People's Charter' call for a system of governance that is characterized by 'transparency and accountability'. Yet, on 17 September 2004, Fiji's highest appellate court, the Supreme Court, comprising the suspended Chief Justice, Justices Robert French and David Malcolm, confirmed a decision of the Court of Appeal that the Auditor General was legally required to audit the regimental funds. ${ }^{l}$ For his part, the commander - and now interim prime minister - Commodore Bainimarama was legally required to allow the Auditor General access for audit purposes to the records and accounts of the regimental funds. There has been no credible evidence that, as a result of the Supreme Court's decision, the regimental funds have been opened for scrutiny by the Auditor General.

The deaths in military custody of Nimilote Verebasaga and Sakiusa Rabaka are now before the courts, but only after the civil authorities were prevailed upon to act. There was only grudging and reluctant cooperation from the military itself. Is this just a continuation of past practice? The brutal killing of Counter Revolutionary Warfare Unit (CRWU) soldiers in military custody in late 2000 remains uninvestigated and the perpetrators have not been prosecuted. Is this the measure of reassurance ordinary citizens can expect from an institution that has made much of its security role? It cannot prescribe accountability and openness for others and not expect to have that standard applied to itself. This is not about pointing fingers or casting blame on anyone. It is about taking responsibility for the alleged wrongdoing of its members, as a result of which families have experienced trauma and tragedy. 
Even governments are accountable under the law. It has been several centuries since the prosecution and subsequent conviction and execution of King Charles I in 1649 for treason established the principle that even an absolute monarch must bend to parliament and the law. But in 2008, in Fiji, it seems that those who are driving the country have little or no regard for the law and none at all for parliament. It may be argued that the ousted government was little better. Perhaps that is true. But it does not excuse.

\section{Threats to judicial independence}

At a conference of government lawyers in 2007, the Commodore brushed aside allegations that the judiciary had been compromised and said: 'Many such allegations come from the very lawyers who have the most to lose from an independent judiciary'. He then went on to say 'We must preserve the true independence of our judiciary and help make it stronger'. ${ }^{2}$ But events before and since that conference have shown that judicial independence has been steadily weakened.

What the Commodore failed to say is that some of the country's most senior judges have themselves pointed to serious threats to the independence of the judiciary and the effective administration of justice. In a statement issued on 3 September 2007, a senior judge of the Court of Appeal, Sir Thomas Eichelbaum, issued a statement on behalf of Justices Barker, Ford, McPherson, Penlington and Smellie saying that 'Justice Gates had taken the administration of the Court out of their hands. He had not consulted them about the sittings held last week and had not even had the courtesy to ask about their availability'. The judges felt that their services were not required and so they resigned. Earlier this year, Justice Roger Coventry resigned from the High Court Bench, bringing to at least ten the number of judges who have left Fiji since December 2006. For a relatively small judiciary, in a small country, that is a remarkable number to depart over such a short period. When the judges themselves start 'voting with their feet' and complaining about the undermining of judicial independence, it is hardly a show of confidence in the judiciary and the direction it is taking. Are they, too, to be accused of playing politics or of being manipulated? Can their determination to defend their judicial independence be somehow dismissed as unimportant?

The Commodore has accused lawyers of 'judge-shopping'. But the same standards did not, apparently, apply to supporters of the military regime. In a confidential letter dated 10 September 2007, the miltary-appointed commissioner of police complained to the Secretary for Justice and Solicitor General that 'adverse reports have been received against Justice Winter and Justice Jitoko for engaging in talks against the RFMF [Republic of Fiji Military Forces]....It would be appreciated in the interest of justice that no cases related or associated with RFMF or its members be presided over by these two judges'. Coming from the 
head of the police force, the commissioner's letter was even more brazen because it could be construed as amounting to a conspiracy to defeat justice. That was at least the view of Justice Winter, who felt at the time that the Penal Code had been broken by the Commissioner himself. What this incident also revealed was that the independence of the police had been compromised. This is hardly surprising given that its head was the second-in-command of the army at the time that it seized power in the December 2006 coup.

The judges criticized were never given an opportunity to defend themselves against the scurrilous allegations which the commissioner assumed to be factual. Justice Winter said at the time, 'The Police Commissioner's action may also constitute a real risk to the authority and independence of the court'. Ironically, in the light of the Commodore's remarks, the commissioner was himself effectively engaging in judge-shopping.

The acting Chief Justice has made no public effort to defend the judges criticized. Nor did the interim Attorney-General stand up to defend 'his' judges. Justice Winter has since resigned. This is to be contrasted with the Attorney-General's swift defence of Justice Scutt when she was the brunt of public criticism after controversially applauding a Fiji Human Rights Commission report casting doubt on the results of the 2006 general election. The Attorney-General was reported to have said that criticism of Scutt was not based on principle but on a personal and political agenda. Owing to the protection of powerful political patrons, judge Scutt felt able to make statements of a politically partisan and controversial nature. Although she was publicly pilloried for this indiscretion, she remains on Fiji's High Court.

There is an increasing perception that some elements in the judiciary think that judges are beyond criticism. At an admission ceremony for new lawyers in February 2008, Mr Justice Devendra Pathik said:

It is a matter of great concern that of recent [sic] the suing of Judges has become a trend. Is it the idea to grind the judicial system to a halt? The Courts will not allow that to happen. Authorities going back to 1880 s do not allow that when a Judge is performing his duty. There is such a concept as 'judicial immunity' and legal practitioners should know that if they know their law well.

The judge was referring to a recent recusal application that he had dismissed. To suggest there was a 'trend' of such cases was perhaps an overstatement. But the comment illustrates just how sensitive some judges are to the suggestion they disqualify themselves from hearing a suit.

At a time when the country's parliament has been suspended and the media is under constant siege, there is a more onerous duty cast upon the judiciary to 
protect the citizenry against the tyranny of the State, and to uphold fundamental rights and freedoms.

Mr Fali Nariman, a respected senior advocate of the Supreme Court of India, recently applauded two Indian judges who he referred to as having indulged in some loud introspection and criticism. These judges were reported as saying, 'Judges must have modesty and humility and not behave like Emperors'.

Mr Nariman concludes his article by saying:

No - we don't need judges who behave like emperors.

What we do need are those:

whom the lust of office does not kill;

whom the spoils of office cannot buy;

who possess opinions and a will;

who have honour; and will not lie;

who can stand before a demagogue

and damn his treacherous flatteries without winking;

tall men (and women), sun-crowned, who live above the fog

in public duty and in private thinking. ${ }^{3}$

There is little question that lawyers have a professional obligation to respect the dignity of the courts. But that does not place judges above fair and measured criticism. It is all too easy to forget that, although judges interpret the law, they are not above it.

But what do outsiders think of Fiji's judiciary? Michael Field, a seasoned journalist who has long followed events in Fiji, had this to say:

The Fiji court system is actually dominated by hard working ethical judges and some of them are even known to excuse themselves from cases where unconstitutional process is under way. But others, motivated by their own role in the coup and self interest, seem willing not only to risk their own reputations, but that of the entire Fiji judiciary. ${ }^{4}$

\section{Blurring of functions}

In February 2008 it was reported on national television that a private law firm, A.K. Lawyers, acting for a limited liability company, had written to the RFMF seeking assistance in enforcing a court order in their client's favour. However well intentioned, the purported use of the military to enforce a court order was misguided and inappropriate. There are established procedures for enforcing judgments of the court. Invoking the help of the army is not one of them. Incidents such as this have merely added to the corrosion of the rule of law by 
circumventing judicial procedures, and wrongly conveying to the military that they might have a role to play in enforcement proceedings. The blurring of the policing and military roles has contributed to a perception that the law enforcement agencies in the country are not independent.

\section{Freedom of expression}

Over the last year or so, persons like Pramod Rae, Ro Teimumu Kepa, Mick Beddoes, Shamima Ali, Reverend Tuikilakila Waqairatu, Kuini Lutua and many others who have expressed opinions on the current situation or commented on various issues, including the policies of the current administration, have been publicly vilified by the interim administration and its lackeys. The US State Department Country Report on Fiji for 2007 noted that, while the constitution provides for freedom of speech and of the press, 'the government did not fully respect these rights in practice'. ${ }^{5}$ Recently, John Ryder, a member of the Provincial Youth Forum, was taken in by military officers for questioning. His 'crime' was trying to organize a youth rally. The police scuttled the rally, saying it would be threat to national security: Never mind the right to freedom of expression and assembly enshrined in articles 31 and 32 of the constitution. And yet the administration insists that the constitution is alive and has not been abrogated.

What is conveniently overlooked is that it is that same constitution which guarantees the right of assembly and free speech and the equality of all (including government) before the law. The right of free speech includes the right to criticize as well as to praise, to applaud as well as to condemn. It includes the right to be unpopular, wrong, irrational, illogical and even perverse. The National Council for Building a Better Fiji calls for a 'sustainable democracy', yet one of the fundamental freedoms, the right to free speech - and thus a free media - is under constant threat. The right of equality before the law is the right to hold a government to the same standards it seeks to impose on its citizens - to insist on due process and an impartial judiciary. These rights have all but disappeared.

Sir Gerard Brennan, a former Chief Justice of Australia, has remarked:

The right to peaceful dissent is not merely something to be tolerated. It is an important safeguard of peace and order; it is a feature of a free society under the rule of law. Subject to the ordinary laws governing the limits of free speech, restriction on the freedom to dissent or to contribute fairly to political discussion is an impairment to the rule of law. ${ }^{6}$

It is difficult to see how 'true democracy' can be promoted when one of its basic tenets, free speech, is regularly curtailed. 
Too often in Fiji, the rhetoric of 'threats to national security' has been in the mouths of those with a motive to suppress and oppress and an interest in maintaining silence, however sullen, in the face of wrongdoing.

\section{Accountability}

The London-based International Bar Association (IBA), comprising more than 195 law associations from around the world, had planned a March 2008 mission to assess the independence of the judiciary in Fiji. Despite the organization's assurance to the regime that they would not impinge in any way through pressure or influence on the courts, the administration's chief apologist accused the IBA of 'being manipulated by powerful elite'. A regime that has lectured the country ad nauseam on the need for good governance, transparency and accountability refused to apply the same standards to itself. The IBA mission would have been an excellent opportunity for the regime to demonstrate just how independent the Fiji judiciary is. The suggestion that the IBA might interfere with ongoing constitutional cases, was a little far-fetched. It is almost as ridiculous as suggesting that the environmental organization Greenpeace would participate in the killing of whales.

Delegates of the proposed IBA mission included a senior judge from Queensland and senior legal practitioners from the Asia-Pacific region and beyond. Reacting to the government's 'ban' on the mission, Supreme Court judge Roslyn Atkinson, who was to be a member of the mission, said, 'I hope that they reconsider and allow the visit to proceed in the interests of openness and accountability'. What the regime's paranoia about external oversight showed was a fear that respected jurists, who had conducted missions to Zimbabwe, Pakistan and Guantanamo Bay, might discover the real situation on the ground. Perhaps the simple truth would have been unpalatable. At the time of writing, the interim administration has apparently had a change of heart and agreed to allow the IBA to visit Fiji.

\section{Attack on press freedom}

Another pillar of democratic governance, press freedom, has been under assault from the interim regime. The regime managed to grab the headlines in Fiji and overseas for the cruel and callous manner in which it abducted and deported Russell Hunter, the publisher of the Fiji Sun in February 2008. What happened was typical of a police state. No due process was followed. Mr Hunter was picked up from his home in Suva at night and taken away by a group of people who, Mr Hunter suspects, included representatives of the army. His abductors did not even allow him time to pack a suitcase, or put some money in his pocket. They confiscated his mobile phone, thus leaving his fearful family wondering about his fate.

Apart from the more sinister aspects of this incident, there was a decided lack of transparency and accountability in the manner in which the newspaper 
publisher was bundled out of Fiji. In fact, there was no transparency, and no accountability.

The persecution of Mr Hunter followed disclosures by his newspaper relating to allegations of tax evasion by interim Minister for Finance Mr Chaudhry, and large overseas deposits held by him.

The Media Council of Fiji and many international media organizations strongly deplored the treatment given to Mr Hunter. The local council asked whether or not other foreign media persons would be dealt with in this way. ${ }^{7}$ It asked what would happen when a local journalist did whatever Mr Hunter was supposed to have done. Would he or she be incarcerated?

\section{Excluding the courts' jurisdiction}

Russell Hunter was expelled despite a court order against this. The interim minister for immigration refused to elaborate on the reasons for Hunter's deportation. Instead, he sought refuge behind a cloak of secrecy, on the ground of national security. There was a decided lack of transparency and accountability in the manner in which the newspaper publisher was bundled out of Fiji.

On the back of Hunter's expulsion in late February, the regime changed the law to allow such expulsions, and to deny the victims legal redress. In an extraordinary edition of the gazette, published on 26 February 2008, it was stated that decisions of the Minister for Immigration under section 13(2) of the Immigration Act 2002 [sic] 'shall be final and conclusive and shall not be questioned or reviewed in any court'. The section sets out a category of persons who are described as a 'prohibited class'; a category that includes persons in respect of whom a deportation order has been made. The new 'law' sought to 'oust the jurisdiction' of the courts. In lay terms, the amendment prevents the courts from questioning the exercise of ministerial power vested in the immigration minister. This questionable law removes the normal checks and balances designed to ensure that the State is acting according to proper legal procedures. It puts the minister's actions beyond judicial scrutiny. In an environment in which it is said the constitution has not been abrogated, one may well ask 'how can this be possible?'

What was even more disturbing was that the law was backdated by a day. Even, assuming that a military regime in a caretaker mode can, through a compliant President, make new law, this attempt at preventing the courts from their traditional function of 'checking' governmental or executive action is a further example of the gradual and continued undermining of the rule of law. This back-dating was clearly calculated to legalize the forced removal from Fiji of a specific individual and is, on this account if no other, contrary to the most fundamental of principles of constitutional law.

Sir Gerard Brennan says: 
If the rule of law is to apply universally, the jurisdiction of the courts to judicially review an exercise of administrative power is essential. To the extent that the courts are denied jurisdiction to review judicially an exercise of administrative power, the power is beyond control by operation of law. If the courts are denied jurisdiction to enforce the law governing the exercise of power, the repository of the power can refuse to obey the law with impunity and the rule of law is negated. ${ }^{8}$

\section{Double standards}

Addressing the Pacific Islands Business Forum in August 2007, Commodore Bainimarama said, 'To tackle corruption, strong and committed leadership is required'. He then quoted from the former Prime Minister of Singapore, Lee Kuan Yew, who had said:

The moment key leaders are less than incorruptible, less than stern in demanding high standards, from that moment the structure of administrative integrity will weaken and eventually crumble...Only when we uphold the integrity of the administration, can the economy work in a way which enables (us) to clearly see the nexus between hard work and high rewards....instead of hoping for a windfall through powerful friends and relatives or through greasing contacts in the right places. ${ }^{9}$

No one would disagree with the Commodore's endorsement of Lee Kuan Yew's views on corruption. They are noble principles worthy of emulation. The real question which must be asked is whether or not the interim administration is keeping to the lofty principles so eloquently articulated by the Commodore. The taxpayers of Fiji are entitled to ask whether or not he has demanded of his ministers the high standards he says he espouses and which he expects of other citizens.

Respected prosecutor Peter Ridgway, no friend of the ousted government, said in a recent interview that Fiji had become 'filled with a thousand little treasons being committed on a daily basis, by police, military, people in power' ${ }^{10} \mathrm{~A}$ slight exaggeration perhaps, but the message is clear. In light of the emerging and known facts, who can disagree with his rather sobering assessment of events in post-coup Fiji? But then maybe Ridgway is lying? Or is he just another expatriate troublemaker? It is hard not to conclude, despite all the spin, that the grave departures from constitutionalism that I alluded to in a speech in Hong Kong in June last year continue. More likely they have intensified. 


\section{ENDNOTES}

1 Commander, Republic of Fiji Military Forces v Auditor General, Supreme Court of Fiji, 17 September 2004

2 Bainimarama, 'Address at the 9th Attorney General's Conference 2007', 30 November 2007, http://www.fiji.gov.fj/publish/page_10719.shtml.

3 Journal of the Commonwealth Lawyers Association Vol. 17, No.1 April 2008, p.26.

4 Michael Field, 'Ethics, media, kidneys and Bainimarama's perversions', 27 February 2008, http://www.michaelfield.org/Baini\%20ethics.htm.

5 http://www.state.gov/g/drl/rls/hrrpt/2007/100520.htm.

6 The Hon. Sir Gerard Brennan AC KBE, 'The Role of the Legal profession in the Rule of Law', Supreme Court, Brisbane, 31 August 2007, available www.lawcouncil.asn.au/shared/2441848483.pdf.

7 Indeed, in May 2008, the publisher of The Fiji Times, Fiji's largest circulation newspaper, Australian Evan Hannah, was similarly deported, despite orders from the High Court restraining the expulsion, and hours after interim Prime Minister Bainimarama had delivered an address honouring World Media Freedom Day.

8 The Hon. Sir Gerard Brennan AC KBE, 'The Role of the Legal profession in the Rule of Law', Supreme Court, Brisbane, 31 August 2007, available at www.lawcouncil.asn.au/shared/2441848483.pdf p.13.

9 Bainimarama, 'Opening Address at Pacific Islands Business Forum', Radisson Resort Fiji, Denarau, 6 August 2007, http://www.fiji.gov.fj/publish/page_9704.shtml.

10 Peter Ridgway, interviewed on 'Fiji's Faltering Freedoms', ABC, The Law Report, 4 March 2008, http://www.abc.net.au/rn/lawreport/stories/2008/2177850.htm. 